\title{
Interactive comment on "Influence of climate variability, fire and phosphorus limitation on the vegetation structure and dynamics in the Amazon-Cerrado border” by Emily Ane Dionizio da Silva et al.
}

Emily Ane Dionizio da Silva et al.

emilyy.ane@gmail.com

Received and published: 31 July 2017

We have attached the responses to Reviewer 3 in link : Supplement (pdf/zip). The pdf file contains the reviewer comments in italics, and the responses in bold.

Please also note the supplement to this comment: 
Interactive comment on Biogeosciences Discuss., https://doi.org/10.5194/bg-2017-149, 2017.

Interactive

comment 